Review

\title{
An Update on the Metabolic Roles of Carbonic Anhydrases in the Model Alga Chlamydomonas reinhardtii
}

\author{
Ashok Aspatwar ${ }^{1, * \mathbb{1}}$, Susanna Haapanen ${ }^{1}$ and Seppo Parkkila ${ }^{1,2}$ \\ 1 Faculty of Medicine and Life Sciences, University of Tampere, FI-33014 Tampere, Finland; \\ Haapanen.Susanna.E@student.uta.fi (S.H.); seppo.parkkila@staff.uta.fi (S.P.) \\ 2 Fimlab, Ltd., and Tampere University Hospital, FI-33520 Tampere, Finland \\ * Correspondence: ashok.aspatwar@staff.uta.fi; Tel.: +358-46-596-2117
}

Received: 11 January 2018; Accepted: 10 March 2018; Published: 13 March 2018

\begin{abstract}
Carbonic anhydrases (CAs) are metalloenzymes that are omnipresent in nature. CAs catalyze the basic reaction of the reversible hydration of $\mathrm{CO}_{2}$ to $\mathrm{HCO}_{3}{ }^{-}$and $\mathrm{H}^{+}$in all living organisms. Photosynthetic organisms contain six evolutionarily different classes of $\mathrm{CAs}$, which are namely: $\alpha$-CAs, $\beta$-CAs, $\gamma$-CAs, $\delta$-CAs, $\zeta$-CAs, and $\theta$-CAs. Many of the photosynthetic organisms contain multiple isoforms of each CA family. The model alga Chlamydomonas reinhardtii contains 15 CAs belonging to three different CA gene families. Of these $15 \mathrm{CAs}$, three belong to the $\alpha$-CA gene family; nine belong to the $\beta$-CA gene family; and three belong to the $\gamma$-CA gene family. The multiple copies of the CAs in each gene family may be due to gene duplications within the particular CA gene family. The CAs of Chlamydomonas reinhardtii are localized in different subcellular compartments of this unicellular alga. The presence of a large number of CAs and their diverse subcellular localization within a single cell suggests the importance of these enzymes in the metabolic and biochemical roles they perform in this unicellular alga. In the present review, we update the information on the molecular biology of all 15 CAs and their metabolic and biochemical roles in Chlamydomonas reinhardtii. We also present a hypothetical model showing the known functions of CAs and predicting the functions of CAs for which precise metabolic roles are yet to be discovered.
\end{abstract}

Keywords: carbonic anhydrases; CA gene family; Chlamydomonas reinhardtii; model alga; metabolic role; photosynthesis

\section{Introduction}

Carbonic anhydrases (EC 4.2.1.1) (CAs) are metalloenzymes that catalyze the reversible reaction of hydration of carbon dioxide to bicarbonate $\left(\mathrm{CO}_{2}+\mathrm{H}_{2} \mathrm{O} \Leftrightarrow \mathrm{HCO}_{3}{ }^{-}+\mathrm{H}^{+}\right)$. The CAs belong to seven evolutionarily unrelated CA-gene families $\left(\alpha-, \beta-, \gamma_{-}^{-}, \delta_{-}, \zeta_{-}, \eta-\right.$, and $\left.\theta-\mathrm{CAs}\right)[1-5]$.

The CAs are widespread in nature, and are found abundantly in plants, animals, and microorganisms, suggesting that the CAs have many diverse metabolic roles in living organisms [6-8]. Vertebrates and mammals have only $\alpha$-CAs and contain multiple isoforms of the enzyme. In contrast, multicellular plants and unicellular photosynthetic organisms seem to have members of six CA gene families, often multiple isoforms of CAs from each gene family $[4,9]$. The Chlamydomonas reinhardtii genome analysis has revealed the presence of at least 15 CA genes encoding three different families of CAs. The number of CAs in C. reinhardtii is thus much higher than previously thought for a unicellular cell alga. Interestingly, a recent study showed that the limiting $\mathrm{CO}_{2}$-inducible B protein (LCIB) family belongs to the $\beta$-CAs [10]. The amino acid sequences of these CA families are different, but most of these CA families have a $\mathrm{Zn}^{2+}$ atom at the active site [11]. In this alga, CAs have been found in the mitochondria, chloroplast thylakoid, cytoplasm, and periplasmic 
space $[12,13]$. A recent study showed that CAH6 is localized in the flagella instead of the pyrenoid stroma, as previously reported [14].

The downregulation of CA activity using molecular techniques and chemical inhibitors has shown reduced lipid biosynthesis in chloroplasts compared with chloroplasts from wild-type plants [15]. CAs are indirectly involved in lipid synthesis (and perhaps other $\mathrm{HCO}_{3}{ }^{-}$-requiring pathways in plastids), serving to "concentrate" $\mathrm{CO}_{2}$ in plastids as $\mathrm{HCO}_{3}{ }^{-}$, and reduce the rate of $\mathrm{CO}_{2}$ diffusion out of plastids [15]. The CA might indirectly influence fatty acid synthesis in plastids by modulating plastidial $\mathrm{pH}$, as the enzyme fatty acid synthase activity requires an optimal $\mathrm{pH}$ for fatty acid synthesis [15].

The role of CAs in pH regulation is well known in animal cells. However, the roles of CAs in $\mathrm{pH}$ regulation in this model alga are not known, and need to be investigated. The presence of 15 CAs in C. reinhardtii suggests that they are involved in several other metabolic functions in addition to a $\mathrm{CO}_{2}$-concentrating mechanism (CCM), which is attributed to the evolutionarily conserved enzymes in plants. In C. reinhardtii, CAs are involved in many metabolic functions that involve carboxylation or decarboxylation reactions, including both photosynthesis and respiration. In addition, it has been clearly shown that CAs also participate in the transport of inorganic carbon to actively photosynthesizing cells and away from nonphotosynthesizing, respiratory cells [12,16].

In the current article, we will review the information on CAs of $C$. reinhardtii, a unicellular model alga. We will describe the information that is available on the molecular biology, and present the data for the metabolic and biochemical roles of the three CA gene families. For each CA enzyme from the three CA families, we will highlight the current research and questions that have been addressed by researchers in the field. We will also present a hypothetical model showing the known functions of CAs and predicting the functions of CAs for which precise metabolic roles are yet to be discovered. Finally, we present future directions in the field of $C$. reinhardtii CA research in order to study the precise metabolic and physiological roles of $\mathrm{CAs}$ from this alga.

\section{General Aspects of Carbonic Anhydrases}

Carbon dioxide $\left(\mathrm{CO}_{2}\right)$ is a very important molecule that is found in all living organisms. $\mathrm{CO}_{2}$ is soluble in lipid membranes, and freely diffusible in and out of the cell [17-19]. Carbon dioxide and bicarbonate constitute the main buffer system for $\mathrm{pH}$ regulation in all living cells. CAs play a very important role in the transport of $\mathrm{CO}_{2}$ and protons across cell membranes [20,21]. CA families differ in their preference for the metal ions used within the active site for performing the catalysis. The general enzyme catalytic mechanism of all of the CAs involves a reaction between a metal cofactor bound to $\mathrm{OH}^{-}$and $\mathrm{CO}_{2}$, giving rise to a $\mathrm{HCO}_{3}{ }^{-}$ion that is subsequently replaced from the metal with an $\mathrm{H}_{2} \mathrm{O}$ molecule. This reaction is shown in Equation (1) below, where Enz indicates CA enzymes, and $\mathrm{M}$ indicates the metal cofactor. The regeneration of $\mathrm{OH}^{-}$involves a transfer of $\mathrm{H}^{+}$from the metal bound to the $\mathrm{H}_{2} \mathrm{O}$ molecule to the solvent, as shown in Equation (2) [22,23].

$$
\begin{gathered}
\text { EnzM }-\mathrm{OH}+\mathrm{CO}_{2} \Leftrightarrow \text { EnzM }-\mathrm{HCO}_{3}-\stackrel{\mathrm{H}_{2} \mathrm{O}}{\Leftrightarrow} \text { EnzM }-\mathrm{H}_{2} \mathrm{O}+\mathrm{HCO}_{3}{ }^{-} \\
\text {EnzM }-\mathrm{H}_{2} \mathrm{O} \Leftrightarrow \text { EnzM-OH }{ }^{-}+\mathrm{H}^{+}
\end{gathered}
$$

CAs are metal-containing enzymes that are found in every living organism and have been studied extensively in the past. These enzymes are widely distributed among metabolically diverse species from all three domains of life. CAs perform various physiological functions, such as respiration, photosynthesis, $\mathrm{pH}$ regulation, ion transport, bone resorption, and the secretion of gastric juice, cerebrospinal fluid, and pancreatic juice $[8,24,25]$. CAs are also involved in electrolyte secretion, $\mathrm{CO}_{2}$ and $\mathrm{pH}$ homeostasis, $\mathrm{CO}_{2}$ fixation, and biosynthetic reactions, such as gluconeogenesis and ureagenesis [26-29].

Although the CA families are diverse and widespread, the current understanding of their biological role is mainly based on studies with several $\alpha$ and $\beta$-class CAs. Among the other CA 
classes, the $\delta$ and $\zeta$ classes have been reported only in diatoms and coccoliths [30,31]. Cam is the $\gamma$-class archetype isolated from Methanosarcina thermophila, an anaerobic methane-producing species from the Archaea domain [9]. The $\eta$ and $\theta$-class CAs have been identified recently from Plasmodium falciparum and marine diatoms, respectively $[1,4]$. The $\alpha$-CAs are typically found as monomers and dimers; the $\beta$-CAs are typically found in many oligomerization states; and the $\gamma$-CAs are typically found as trimeric forms. Table 1 shows details of all of the CA gene families of enzymes, and Figure 1 depicts example structures of the major CA families: $\alpha, \beta$, and $\gamma$.

Table 1. Details of the carbonic anhydrase (CA) gene family enzymes in living organisms.

\begin{tabular}{ccccc}
\hline CAs & Enzyme & Metal Ion & Organisms & Ref. \\
\hline$\alpha$ & Monomeric, dimeric & $\mathrm{Zn}^{2+}$ & Animals, prokaryotes, fungi, and plants & {$[8,32]$} \\
$\beta$ & Multimeric & $\mathrm{Zn}^{2+}$ & Plants, bacteria, and fungi & {$[8,32]$} \\
$\gamma$ & Trimeric & $\mathrm{Zn}^{2+}$ or Fe, Co & Plants, archaea, fungi, and bacteria & {$[33,34]$} \\
$\zeta$ & Monomeric & $\mathrm{Cd} \mathrm{or} \mathrm{Zn}$ & Marine diatoms & {$[30,33,34]$} \\
$\delta$ & Monomeric & $\mathrm{Co}$ & Marine diatoms & {$[30,35,36]$} \\
$\eta$ & Monomeric & $\mathrm{Zn}^{2+}$ & Plasmodium spp. & {$[1,37]$} \\
$\theta$ & Monomeric & $\mathrm{Zn}^{2+}$ & Marine diatoms & {$[4,9,10]$} \\
\hline
\end{tabular}

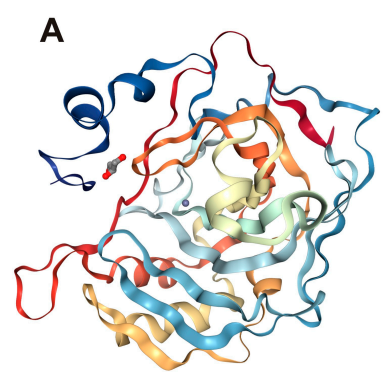

D

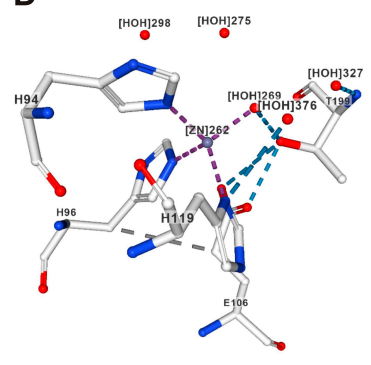

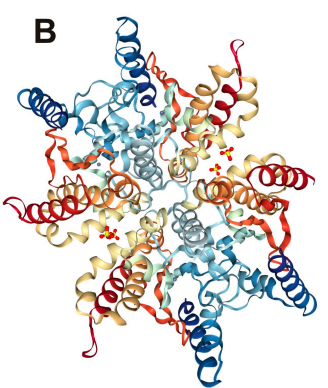

E

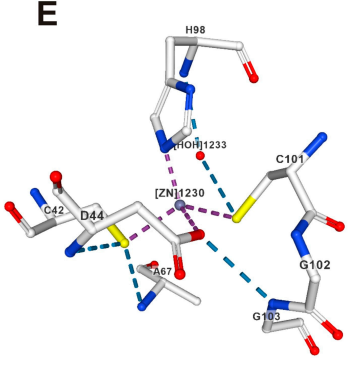

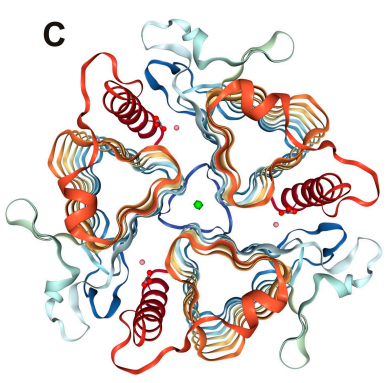

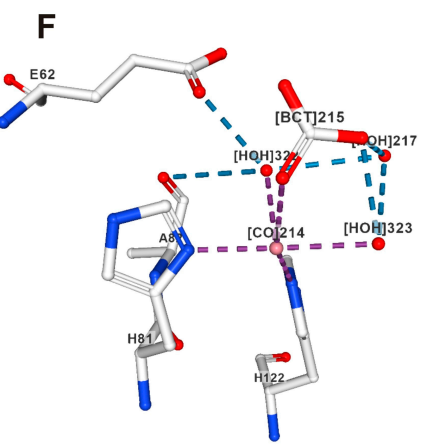

Figure 1. Representative structures of the $\alpha$-CA, $\beta$-CA, and $\gamma$-CA families of enzymes and their ligand-binding sites. (A) Structure of human CAII enzymes retrieved from PDB 3U45. The human CAII monomer mostly consists of beta strands and contains a single active site with three zinc-coordinating histidine residues [38,39]; (B) Structure of Haemophilus influenzae $\beta-C A$ retrieved from PDB 2A8C [40]; (C) Structure of $\gamma$-CA from Methanosarcina thermophila 1QRE [41,42]; (D-F) Metal at the active site coordinated with histidine residues (purple), hydrogen bonds (blue), halogen bonds (turquoise), hydrophobic contacts (gray), and pi interactions (orange, green). Images D and $\mathrm{E}$ show $\mathrm{Zn}^{2+}$ at the active site, and image $\mathrm{F}$ shows the $\mathrm{Co}^{2+}$ substitution in the structure.

The $\alpha$-carbonic anhydrases: Among the CA gene families, the $\alpha$-CA was first to be discovered in 1932 in erythrocytes [43,44]. Among the CA gene families, $\alpha$-CAs are the most widely distributed CA family. $\alpha$-CAs are also the most studied CA-group, probably because all of the human CAs belong to this enzyme family. In humans, there are $15 \alpha$-CA family isoforms; among these, $12 \alpha$-CA isoforms are catalytically active, and three CAs do not have catalytic activity, and are designated carbonic 
anhydrase-related proteins (CARPs) [45]. The $\alpha$-CAs are monomers that are found in every type of tissue; furthermore, these enzymes have unique localizations within the cell. These enzymes have $\mathrm{Zn}^{2+}$ as a metal ion at their active site, and are coordinated by three histidine residues. The $\alpha$-CAs play a wide variety of roles in living organisms.

The $\beta$-carbonic anhydrases: The first $\beta$-CA was discovered in 1938, and subsequently, many $\beta$-CAs have been reported from bacteria, archaea, yeasts, algae, and plants $[32,46,47]$. The $\beta$-CAs contain $\mathrm{Zn}^{2+}$ as the metal ion at the active site of the enzyme. In $\beta$-CAs, the $\mathrm{Zn}^{2+}$ atom is coordinated by two cysteines and one histidine, unlike the three histidines found in $\alpha$ and $\gamma$-CAs [48]. Some of the enzymes in the $\beta$-CA class have four zinc ligands, that is, one His residue, two Cys residues, and one Asp residue coordinated to $\mathrm{Zn}^{2+}$ [49]. $\beta$-CAs are found in many oligomerization states due to the presence of an $\alpha / \beta$-fold that promotes an association with the formation of dimers. Several crystal structures of $\beta$-CAs have already been reported [50-52]. The $\beta$-CAs play important roles in $\mathrm{CO}_{2}$ fixation in plants and other photosynthetic organisms, as well as in $\mathrm{pH}$ regulation, survival, virulence, and invasion in bacteria [53-55].

The $\gamma$-carbonic anhydrases: The $\gamma$-CAs were discovered in 1994, and are found in Archaea, Bacteria, and plants $[56,57]$. These enzymes are trimers, unlike the other CA gene families. The $\gamma$-CAs contain $\mathrm{Zn}^{2+}$ at the active site, and in some cases, the enzymes contain $\mathrm{Fe}^{2+}$ instead of the $\mathrm{Zn}^{2+}$ that is found in anaerobic Archaea [58]. The active site metal is coordinated by three histidine ligands and one water molecule [42]. The kinetic studies of $\gamma$-CA from $M$. thermophila showed that the hydration of $\mathrm{CO}_{2}$ is a two-step process similar to that in $\alpha$-CAs $[59,60]$.

The $\delta$-carbonic anhydrases: The first $\delta$-CA was characterized from Thalassiosira weissflogii, a unicellular microalga representing a species of centric diatoms [61]. The $\delta$-CAs are also present in many eukaryotic marine phytoplanktons $[8,61]$. The crystal structure of $\delta$-CAs has not been resolved, but studies using X-ray absorption spectroscopy methods have shown that the metal ion $\mathrm{Zn}$ is coordinated by histidine ligands similar to those in the $\alpha$ and $\gamma$ classes of CAs [48].

The $\zeta$-carbonic anhydrases: $\mathrm{Xu}$ et al. described the $\zeta$-CAs in marine diatoms in 2008 [8]. The $\zeta$-CAs contain cadmium at the active site of the enzyme as an alternative metal cofactor [33]. The structure of CdCA1 has been resolved, and it is reported that the metal-binding region is repeated three times in this enzyme [62]. The $\zeta$-CAs have been shown to bind to other metals apart from $\mathrm{Cd}$ and remain active. The reason for having $\mathrm{Cd}$ at their active site is possibly adaptation in the ocean, where $\mathrm{Zn}$ levels are often low.

The $\eta$-carbonic anhydrases: $\eta$-CA is a novel class of CA that Del Prete et al. recently discovered recently [1]. The $\eta-C A$ is found in the malaria-causing protozoan parasite Plasmodium falciparum. The active site of $\eta-C A$ contains $\mathrm{Zn}^{2+}$, and is coordinated by two Hi residues and one Gln residue, in addition to the water molecule/hydroxide ion acting as a nucleophile in the catalytic cycle [37]. This arrangement is unique compared with that in the other CA gene families [37].

The $\theta$-carbonic anhydrases: The $\theta-C A$ family is a recent addition to the existing CA gene family, as reported by Kikutani et al. [4] in 2016. These CAs have also been described in a cyanobacterium by Jin et al. [10]. The $\theta$-CAs are implicated in the formation of $\mathrm{CO}_{2}$ from $\mathrm{HCO}_{3}{ }^{-}$in the chloroplast.

\subsection{Carbonic Anhydrases in Photosynthetic Organisms}

Photosynthetic organisms contain CAs that belong to six different CA gene families, namely: $\alpha$-CAs, $\beta$-CAs, $\gamma$-CAs, $\delta$-CAs, $\zeta$-CAs, and $\theta$-CAs. Each of the at least three gene families of $\alpha$-CAs, $\beta$-CAs, and $\gamma$-CAs are represented by multiple isoforms in all of the species. The $\gamma$-CAs are also found in photosynthetic bacteria $[63,64]$. $\theta$-CA has been recently discovered in the thylakoid lumen of the marine diatom Phaeodactylum tricornutum [4]. The four CA gene families $\left(\alpha_{-}, \beta_{-}, \gamma_{-}\right.$, and $\theta_{-}$-CAs) that are found in photosynthetic organisms contain zinc as a metal ion at the active site of the enzymes $[4,8]$. Due to the alternative splicing of CA transcripts, the number of functional CA isoforms in many of the species is greater than the number of genes that encode a particular CA enzyme. In photosynthetic organisms, CAs are expressed in different cellular compartments, and are most 
prevalent in chloroplasts, cytosol, and mitochondria. The diversity in location suggests the importance of the CAs in the many physiological and biochemical roles they may play in photosynthetic organisms.

\subsection{Carbonic Anhydrases in Chlamydomonas Reinhardtii}

The model alga Chlamydomonas reinhardtii is a unicellular photosynthetic eukaryote that contains multiple genes encoding CAs for three different gene families. The $\alpha$-CAs were discovered in the 1980s and 1990s in C. reinhardtii $[12,65,66]$. The $\beta$-CAs were discovered during the 1990s, [67-69], and with the sequencing of the complete genome of $C$. reinhardtii, three novel $\gamma$-CAs were found in the latter part of the 2000s [57,70-72].

The alga $C$. reinhardtii has three $\alpha$-CAs, nine $\beta$-CAs (including the recently discovered three homologs of the LCIB protein family), and three $\gamma$-CAs [10]. Among the CAs that are found in C. reinhardtii, the $\beta$-CAs are predominant, with the highest isozyme number in this organism. Details of all the CAs that have been discovered in C. reinhardtii to date are presented below (Table 2).

Table 2. Details of the 15 carbonic anhydrases found in Chlamydomonas reinhardtii belonging to the $\alpha, \beta$, and $\gamma$ gene families.

\begin{tabular}{|c|c|c|c|c|c|c|}
\hline CA Protein & Chr & $\begin{array}{l}\text { Gene } \\
\text { Family }\end{array}$ & $\begin{array}{c}\text { MW } \\
(\mathbf{k D a})\end{array}$ & Location & $\begin{array}{c}\text { Known/Predicted Physiological } \\
\text { Roles of the CAs }\end{array}$ & References \\
\hline $\mathrm{CAH} 1^{\mathrm{a}}$ & 4 & \multirow{3}{*}{$\alpha$} & 78 & $\begin{array}{c}\text { Periplasm/late } \\
\text { secretory pathway }\end{array}$ & Supply of $\mathrm{Ci}$ in low $\mathrm{CO}_{2}$ & {$[66,73-79]$} \\
\hline $\mathrm{CAH} 2^{\mathrm{a}}$ & 4 & & 84 & $\begin{array}{c}\text { Periplasm/late } \\
\text { secretory pathway }\end{array}$ & Supply of $\mathrm{Ci}$ in high $\mathrm{CO}_{2}$ & {$[14,66,80,81]$} \\
\hline $\mathrm{CAH}^{\mathrm{a}}$ & 9 & & 29.5 & Chloroplasts & Growth in low $\mathrm{CO}_{2}$ & {$[14,82-88]$} \\
\hline $\mathrm{CAH} 4{ }^{*, \mathrm{a}}$ & 5 & \multirow{9}{*}{$\beta$} & 21 & Mitochondria & - & {$[14,89-91]$} \\
\hline $\mathrm{CAH} 5 *$ a & 5 & & 21 & Mitochondria & - & {$[14,40-42]$} \\
\hline $\mathrm{CAH6}^{\mathrm{a}}$ & 12 & & 31 & Flagella & $\mathrm{CCM}$ & [14] \\
\hline $\mathrm{CAH7}^{\mathrm{b}}$ & 13 & & 35.79 & Periplasm? & - & [92] \\
\hline $\mathrm{CAH}^{\mathrm{a}}$ & 9 & & 35.79 & Periplasm & - & [92] \\
\hline $\mathrm{CAH9}^{\mathrm{a}}$ & 5 & & 13.06 & Cytosol & - & [14] \\
\hline LCIB1 $^{\mathrm{b}}$ & & & $48^{c}$ & Chloroplasts & $\mathrm{CO}_{2}$, uptake, $\mathrm{CCM}$ & [10] \\
\hline LCIB2 $^{b}$ & & & $48^{c}$ & Chloroplasts & $\mathrm{CO}_{2}$, uptake, $\mathrm{CCM}$ & [10] \\
\hline LCIB3 $^{b}$ & & & $48^{c}$ & Chloroplasts & $\mathrm{CO}_{2}$, uptake, $\mathrm{CCM}$ & [10] \\
\hline CAG1 ${ }^{b}$ & 9 & \multirow{3}{*}{$\gamma$} & 24.29 & Mitochondria & $\begin{array}{c}\text { Transport of mitochondrial } \mathrm{CO}_{2} \\
\text { to chloroplasts }\end{array}$ & {$[14,70,71,93]$} \\
\hline $\mathrm{CAG} 2^{\mathrm{b}}$ & 6 & & 31.17 & Mitochondria & $\begin{array}{l}\text { Transport of mitochondrial } \mathrm{CO}_{2} \\
\text { to chloroplasts }\end{array}$ & {$[14,71,72,93]$} \\
\hline $\mathrm{CAG}^{\mathrm{b}}$ & 12 & & 32.69 & Mitochondria & $\begin{array}{c}\text { Transport of mitochondrial } \mathrm{CO}_{2} \\
\text { to chloroplasts }\end{array}$ & {$[14,71,72,93]$} \\
\hline
\end{tabular}

${ }^{*}$ The amino acid sequences of these two $\beta$-CAs differ by a single amino acid. ${ }^{a} \mathrm{CA}$ activity is known; ${ }^{\mathrm{b}} \mathrm{CA}$ activity is not known; ${ }^{\mathrm{c}}$ Predicted molecular weight. $\mathrm{Chr}=$ chromosome.

\subsection{1. $\alpha$-Carbonic Anhydrase 1}

Among the CA genes, $\alpha$-Ca1 was the first gene that was identified in C. reinhardtii in the 1980s [65,66,94]; it was named Ca1, reflecting the order of discovery. Several groups have shown that CAH1 is localized in the periplasmic space of the alga $[65,66,94]$. Cah1, the gene encoding CAH1, has been cloned [78]. The cDNA encodes a polypeptide of 377 amino acid residues. It is composed of a signal peptide that is 20 amino acids long, a small subunit, a large subunit, and a spacer region between the subunits [76,78]. Fujiwara et al. [66] discovered that the gene sequence is $93.6 \%$ identical to the sequence of $\mathrm{Cah} 2$, which encodes CAH2. In addition, their intron insertion sites are identical. These findings indicate that Cah1 and Cah2 are paralogs or the products of gene duplication [66]. 
The expression of $\mathrm{CAH} 1$ can be induced in the presence of low amounts of $\mathrm{CO}_{2}$ compared to high amounts of $\mathrm{CO}_{2}$. However, Kucho et al. [75] showed that in addition to low amounts of $\mathrm{CO}_{2}, \mathrm{CAH} 1$ requires the presence of light for its induction [75]. Additional studies have shown an accumulation of $\mathrm{CAH} 1$ when the $\mathrm{CO}_{2}$ concentration is reduced in the presence of light $[65,66]$. Inhibition of the photosynthetic reaction using 3-(3,4-dichlorophenyl)-1,1-dimethylurea (DCMU) leads to a reduction in CAH1 mRNA, suggesting that the accumulation of CAH1 mRNA requires functioning photosynthesis [65]. $\mathrm{CO}_{2}$ regulates the induction of $\mathrm{CAH} 1$ through various enhancer and silencer sites [75]. At least a 692-bp region from -651 to +41 relative to the transcription start site was detected to be adequate for the full induction of $\mathrm{CAH} 1$ in response to light and low $\mathrm{CO}_{2}$ [75]. Kucho et al. [75] identified a crucial regulatory area ( $63 \mathrm{bp}$ from -293 to -231 relative to the transcription start site) that contains two enhancer elements. In addition, they detected DNA-binding proteins that specifically interact with these enhancer elements in the presence of light and low $\mathrm{CO}_{2}$ conditions [74]. Additionally, other silencers and enhancers have been found, but they are usually responsible for only small changes in the induction or downregulation of CAH1 [75].

The physiological role of $\mathrm{CAH} 1$ has already been extensively discussed in the earlier review [12]. CAH1 provides more $C_{i}$ to the $C$. reinhardtii cell in a $C_{i}$-deficient environment [12]. Nonetheless, many studies have shown that $\mathrm{CAH} 1$ mutant cells are as viable as the wild type under the conditions assayed. In contrast, drug inhibition restricts the growth, which indicates that other CAs, such as CAH2 and CAH8, might maintain the necessary CA activity in CAH1-deficient cells [12].

\subsection{2. $\alpha$-Carbonic Anhydrase 2}

CAH2 was discovered at same time as CAH1 by Fukuzawa et al. [65,80,81]. CAH2 is a periplasmic protein and is a heterotetramer, as is CAH1. CAH2 consists of two identical large subunits and two small subunits [66]. The molecular weight of the holoenzyme is approximately $84.5-87.9 \mathrm{kDa}$. The large subunit is $38 \mathrm{kDa}$ in size, and the small one is $4.2 \mathrm{kDa}$, which are result of the cleavage of the subunits of the proprotein. Therefore, the subunits are comparatively larger than the corresponding units in CAH1 [80]. The genetic similarity has already been stated, but the similarity of the amino acid sequences is $91.8 \%$ [66]. Nevertheless, the catalytic activity of CAH2 is approximately 1.6 times that of CAH1, as that of CAH2 is 3300 units per mg protein compared to 2200 units per mg protein with CAH1 [80]. The subunits of CAH2 are bound to each other with disulfide bonds, as in CAH1. $\mathrm{CAH} 2$ also has similar glycosylation sites to those of CAH1 in the large subunit [80].

The expression of $\mathrm{CAH} 2$ is more abundant than that of $\mathrm{CAH} 1$, and the expression of $\mathrm{CAH} 2$ is greatly induced in low $\mathrm{CO}_{2}$ conditions as opposed to $\mathrm{CAH1}$, which is moderate in amount and is present in high $\mathrm{CO}_{2}$ conditions [66]. Furthermore, Tachiki et al. [80] have suggested that $\mathrm{CAH} 2 \mathrm{might}$ be present in low as well as high $\mathrm{CO}_{2}$ conditions, as Cah2 mRNA is expressed in both conditions [80]. The function and role has been suggested to be the same as that of CAH1, and Rawat et al. [81] proposed that Cah2 could represent a gene duplication, without a specific role of its own [81].

\subsection{3. $\alpha$-Carbonic Anhydrase 3}

Among the $\alpha$-CAs of $C$. reinhardtii, Karlsson et al. identified $\alpha$-CAH3 in the late 1990s [82], and showed that it was localized in the thylakoid lumen [82,84,91]. CAH3 is a 29.5-kDa polypeptide that Karlsson et al. originally isolated in 1995 [84]. The longest cDNA clone obtained from the cDNA library consisted of $1383 \mathrm{bp}$ and contained an open reading frame that encoded a polypeptide of 310 amino acids [82].

CAH3 functions in the thylakoid lumen, and has been suggested to be part of photosystem II (PSII) or CCM $[13,88,95,96]$. Hanson et al. [13] showed that cia3, which is a mutant line of $C$. reinhardtii lacking functioning $\mathrm{CAH} 3$, has a limiting effect on the function of Rubisco in vivo [13]. The physiological function of CAH3 is also related to the location within thylakoids; thus, in stromal thylakoids, CAH3 is probably associated with light reactions of photosynthesis, and in the intrapyrenoid thylakoids, CAH3 is presumably connected to the actions of Rubisco [88]. 
In addition, the actions of CAH3 are connected to the fatty acid composition of the thylakoid membranes [88]. In low $\mathrm{CO}_{2}$ conditions, the activity of CAH3 is implicitly related to an increase in the relative amount of polyunsaturated fatty acids. The change in the fatty acid composition changes the fluidity of the membranes and, therefore, the ion transport across the thylakoid membrane. The desaturation of fatty acids also provides $\mathrm{H}^{+}$ions, and hence implies that there is a reaction where $\mathrm{H}^{+}$ions are needed [88].

The regulation of $\mathrm{CAH} 3$ in different $\mathrm{CO}_{2}$ conditions differs from the regulation of $\mathrm{CAH} 1$ or $\mathrm{CAH} 2$. It has been found that the activity and localization of $\mathrm{CAH} 3$ changes according to the $\mathrm{CO}_{2}$ conditions, unlike the case with CAH1 [85]. Blanco-Rivero et al. [85] discovered that the amount of mRNA or the actual protein did not increase significantly during acclimation to low $\mathrm{CO}_{2}$ conditions [85]. However, the activity of CAH3 increased due to phosphorylation, as did the amount of CAH3 in intrapyrenoid thylakoids at the expense of stromal thylakoids [85].

Additionally, the optimal $\mathrm{pH}$ of CAH3 is more acidic [87] than that of other CAs of C. reinhardtii. Benlloch et al. [87] measured the activity of $\mathrm{CAH} 3$ at different $\mathrm{pH}$ values, and discovered that the optimum was approximately $\mathrm{pH} 6.5$ compared with that of the other CAs, which function best around a neutral $\mathrm{pH}$. The activity also persists at a higher level than the activity of the other $\mathrm{CAs}$ at lower $\mathrm{pH}$ values [87].

A recent study showed that CAH3a associates with TAT2 and TAT3 proteins of the twin arginine translocation (Tat) pathway, and delivers substrate proteins to the thylakoid lumen [14]. The study also showed that the interaction between CAH3 and STT7 phosphorylates CAH3, CAH3 increases its catalytic activity when $\mathrm{CO}_{2}$ is low, and $\mathrm{CAH} 3$ converts $\mathrm{HCO}_{3}{ }^{-}$to $\mathrm{CO}_{2}$ in thylakoid membranes that traverse the pyrenoid, supplying the pyrenoid with the high concentration of $\mathrm{CO}_{2}$ that is essential for CCM [14,82].

\subsection{4. $\beta$-Carbonic Anhydrase 4}

Eriksson et al. reported the presence of a CA in C. reinhardtii that belongs to the $\beta$-CA family in 1995 [91]. The CAH4 is localized in the mitochondria of C. reinhardtii, and has a molecular mass of 20.7-22 kDa. The gene coding CAH4 is called $\beta-C a 1$, of which the whole nucleotide sequence has been examined, and was found to have $96 \%$ identity with another mitochondrial CA5 (CAH5) coding gene, $\beta$-Ca2 [91]. $\beta$-Ca1 is induced in low $\mathrm{CO}_{2}$ conditions, but not in high $\mathrm{CO}_{2}$ conditions; hence, it is present only when $\mathrm{CO}_{2}$ levels are high [91].

There have been many theories about the physiological role of CAH4 and CAH5. On one hand, Eriksson et al. [91] suggested that they are used in buffering reactions in changing $\mathrm{CO}_{2}$ conditions [91]. Glycine decarboxylation in photorespiration produces excessive amounts of $\mathrm{CO}_{2}$ and $\mathrm{NH}_{3}$ in low $\mathrm{CO}_{2}$ conditions. $\mathrm{H}^{+}$is used because $\mathrm{NH}_{3}$ forms $\mathrm{NH}_{4}{ }^{+}$at the $\mathrm{pH}$ of the mitochondrial matrix. Due to the need for $\mathrm{H}^{+}, \mathrm{CAH} 4$ catalyzes the hydration of $\mathrm{CO}_{2}$ to be faster in order to maintain the $\mathrm{pH}$ in the matrix [91]. On the other hand, Raven hypothesized that there might be a $\mathrm{HCO}_{3}{ }^{-}$channel in the inner mitochondrial membrane; thus, both $\mathrm{CAH} 4$ and $\mathrm{CAH} 5$ have a role in preserving the $\mathrm{CO}_{2}$ [89].

There is also a third hypothesis for the function of CAH4 and CAH5, suggesting that they might provide $\mathrm{HCO}_{3}{ }^{-}$for reactions catalyzed by phosphoenolpyruvate carboxylase where $\mathrm{N}$ is combined to $C$ skeletons that can be later used in protein synthesis [89]. It has also been shown that because of this assumed function, the external $\mathrm{NH}_{4}{ }^{+}$concentration is an essential regulator of the expression and function of CAH4 [89].

\subsection{5. $\beta$-Carbonic Anhydrase 5}

Eriksson at al. identified CAH4 and CAH5 simultaneously in C. reinhardtii [91]. The two clones that code for CAH4 and CAH5 differ only slightly in their nucleotide sequences. In the coding area, the difference is only seven nucleotides, leading to one amino acid change at position 53 , where serine is replaced by alanine [91]. In addition, the upstream regulating sites of $\beta$-Ca1 and $\beta$-Ca2 are very similar. Due to the striking similarity of $\beta-C a 1$ and $\beta-C a 2$, the genes are likely to be duplicates that 
were selected because they increased the quantity of mtCA [90]. CAH4 and CAH5 lack any known functional difference, which also supports the gene-duplication assumption [90].

\subsection{6. $\beta$-Carbonic Anhydrase 6}

Mirta et al. discovered CAH6 in 2004 [97], and showed it to be localized in the chloroplast stroma $[97,98]$. In contrast, localization studies performed by Mackinder et al. [14] recently showed that CAH6 is expressed in flagella and shows no detectable signal in chloroplasts [14]. To validate their findings, the authors analyzed the presence of CAH6 in proteomic datasets, and showed it in the flagellar proteome and in intraflagellar transport (IFT) cargo [14].

The cDNA of Cah6 is 2886 bp long and encodes a 264-amino-acid-long polypeptide, CAH6. CAH6 has a calculated molecular mass of $26 \mathrm{kDa}$, but experimentally, it has a mass of $28.5 \mathrm{kDa}$ in an SDS-polyacrylamide gel [97]. Some amount of $\mathrm{CAH} 6$ expression is induced in low $\mathrm{CO}_{2}$ conditions, but its expression levels are high in high $\mathrm{CO}_{2}$ conditions, similar to the case with many other $\mathrm{CA}$ isoenzymes in C. reinhardtii. CAH6 was believed to be involved in trapping $\mathrm{CO}_{2}$ that is leaking out of pyrenoids by converting it to $\mathrm{HCO}_{3}{ }^{-}$and thus preventing $\mathrm{C}_{\mathrm{i}}$ from leaving the chloroplast [97].

However, a recent study showing the localization of CAH6 to be in the flagella suggested that CAH6 is not required in the chloroplast, as its presence in the chloroplast may short circuit the CCM by converting $\mathrm{CO}_{2}$ from $\mathrm{HCO}_{3}{ }^{-}$and its subsequent release away from Rubisco [14]. Indeed, this is the case at least in cyanobacteria, where the presence of CA disrupts the CCM [99]. Chlamydomonas are known to show chemotaxis toward $\mathrm{HCO}_{3}{ }^{-}$, and $\mathrm{CAs}$ have been implicated in $\mathrm{C}_{\mathrm{i}}$ sensing, and hence may be directly involved in sensing $C_{i}[14,100,101]$.

\subsection{7. $\beta$-Carbonic Anhydrase 7}

Ynalvez et al. identified CAH7 in 2008 [92] by examining the sequences of two genes that code for CAs, namely, CAH7 and CAH8 [92]. The identified gene sequence of Cah7 contains $5077 \mathrm{bp}$. The protein product of the gene Cah7 has 399 amino acids, including 23 amino acids that are well conserved in $\beta$-CAs, as well as two cysteines and one histidine, which coordinate $\mathrm{Zn}^{2+}$. In addition, the researchers predicted that $\mathrm{CAH7}$ has a transmembrane domain, and thus might be attached to a membrane [92].

The amount of CAH7 in the cell depends upon the levels of $\mathrm{CO}_{2}$ in the surroundings. The CAH7 is more abundant in low than in high $\mathrm{CO}_{2}$ conditions. Overall, $\mathrm{CAH7}$ is expressed in lower amounts than most of the other CAs in C. reinhardtii. The location and physiological role of CAH7 in the cell is yet to be resolved [92].

\subsection{8. $\beta$-Carbonic Anhydrase 8}

Ynalvez et al. identified C. reinhardtii CAH8 [92] in 2008 with CAH7, and both sequences were found to be closely related to each other [92]. The cDNA coding for CAH8 contains $2649 \mathrm{bp}$ corresponding to a 333-amino-acid-long polypeptide. Furthermore, CAH8 has the same $\beta$-CA characteristics as CAH7, except that CAH8 has 22 of the 23 well-conserved amino acid residues. The molecular mass of CAH8 is approximately $40 \mathrm{kDa}$. Additionally, CAH8 has the same transmembrane domain near the C-terminus, which is similar to the transmembrane domain of CAH7. Immunolocalization studies have shown that CAH8 is located in the periplasmic space along with $\mathrm{CAH} 1$ and $\mathrm{CAH} 2$, but that the localization of $\mathrm{CAH} 8$ appears closer to the cell membrane compared with that of CAH1 [92].

The expression of CAH8 is constant in the algal cell, but the amount of enzyme is present in higher amounts in the presence of abundant $\mathrm{CO}_{2}$ than in the presence of lower $\mathrm{CO}_{2}$ amounts [92]. The overall expression of CAH8 resembles that of CAH6, as it is moderate among the CAs in C. reinhardtii. There are some theories regarding the function of CAH8. First, it has been suggested that, because CAH8 is closely related to the cell membrane, it would ensure the presence of $\mathrm{CO}_{2}$ near the membrane, despite the external $\mathrm{pH}$ conditions. Second, $\mathrm{CAH} 8$ has been proposed to be a part of 
the $\mathrm{C}_{\mathrm{i}}$ delivery system as a carbon-binding protein. Third, an association with a pore or a channel has been proposed [92].

\subsection{9. $\beta$-Carbonic Anhydrase 9}

The presence of CAH9 in C. reinhardtii was first reported in 2005 by Cardol et al. [71] from the genome sequencing project [71]. The RNA-Seq data that are available suggest that CAH9 is expressed at low levels (http:/ / genomes.mcdb.ucla.edu/Cre454/) under the growth conditions that were used in the experiment at that time [12]. Since then, no further studies have been done on CAH9 expression and its role in C. reinhardtii.

\subsubsection{Limiting $\mathrm{CO}_{2}$ Inducible-B Protein/ $\beta$-Carbonic Anhydrase Family}

Limiting $\mathrm{CO}_{2}$ inducible-B protein (LCIB) is a key player in the eukaryotic algal CCM function in Chlamydomonas reinhardtii [100]. The LCIB gene encodes a novel chloroplast protein that consists of 448 amino acids with a predicted MW of $48 \mathrm{kDa}$, and forms a heteromultimeric complex with its close homolog LCIC; the complex may be tightly regulated or may require additional factors for proper functioning $[14,98,100]$. Interestingly, a recent study involving a double mutant analysis of LCIB/CAH3 showed that LCIB functions downstream of CAH3. It has been hypothesized that LCIB captures $\mathrm{CO}_{2}$ that leaked from the pyrenoid, possibly by unidirectionally hydrating $\mathrm{CO}_{2}$ back to $\mathrm{HCO}_{3}-$ [101]. Recently, in order to study the function of LCIB, a phylogenetically diverse set of recombinant LCIB homologs were produced in E. coli and purified [10]. Structural characterization of the purified proteins showed that three of the six homologs were structurally similar to the $\beta$-CAs at the level of the overall fold, zinc binding motif, and active site architecture. However, none of the three proteins showed CA enzymatic activity, and the lack of CA activity could be due to the widening of the intersubunit cleft, which affects active site integrity by causing disordering of the important His162/161 and Arg194/193 residues in the protein [10].

Based on the results of the study, it is proposed that LCIB in association with LCIC acts as a noncatalytic structural barrier for the leaked $\mathrm{CO}_{2}$ from the pyrenoid [10]. However, in order to elucidate the precise role of LCIB, further studies are needed involving the characterization of a LCIB-LCIC complex purified from a native source.

\subsubsection{1. $\gamma$-Carbonic Anhydrases}

The gene Glp1 that encodes $\gamma$-CAH1 was discovered in 2005 using the $\gamma$-CA protein sequence of $M$. thermophila and expressed sequence tag (EST) databases [70]. Similarly, the presence of three $\gamma$-CAs (CAG1, CAG2, and CAG3) in C. reinhardtii was also shown by two other groups, and these were predicted to be localized in the mitochondrial matrix [71,72].

The Glp1 gene that codes for $\gamma$-CAH has seven exons and six introns, and encodes a putative protein of 312 amino acids [70]. The localization studies using prediction programs showed that this enzyme is localized in the cytoplasm or is secreted outside the cell. $\gamma$-CAH1 has approximately $40 \%$ similarity with the $\gamma$-CAH of $M$. thermophila, and has three histidine residues coordinating zinc at the active site of the enzyme. The recombinant proteins expressed in E. coli show no CA activity in either crude cell extracts or purified fusion protein [70]. However, the $\gamma$-CAHs may be active in the parent organism.

There are two additional $\gamma$-CAHs that have been annotated as subunits of the mitochondrial NADH dehydrogenase complex [70]. The sequence analysis showed that these $\gamma$-CAHs do not contain three histidine residues that are required for the catalytic activity of the CAs [70]. Based on the available studies, the $\gamma$-CAHs of $C$. reinhardtii are localized in the mitochondrial matrix, and are part of mitochondrial complex I. Interestingly, complex I of the mitochondrial electron transport chain (mETC) in Arabidopsis thaliana also contains three different protein domains that are homologous to $\gamma$-CAs [102]. Double mutants of Arabidopsis thaliana lacking $\gamma$-CAH1 and $\gamma$-CAH2 were analyzed for their role in development and physiology. The analysis of mutant strains of $A$. thaliana showed a developmental 
delay and an upregulation of complex II and complex IV, with increased oxygen consumption in mitochondrial respiration [102]. The results of this study suggest that the three $\gamma$-CAHs in C. reinhardtii may perform similar functions. The few studies on $\gamma$-CAHs were conducted a decade ago; therefore, the information on the physiological roles of these CAs is incomplete. We need more studies using bioinformatic and molecular tools for the structural and functional analysis of these $\gamma$-CAHs in order to know their precise roles in C. reinhardtii. Based on the latest information we propose a hypothetical model showing the localizations and functions of CAs in C. reinhardtii (Figure 2).

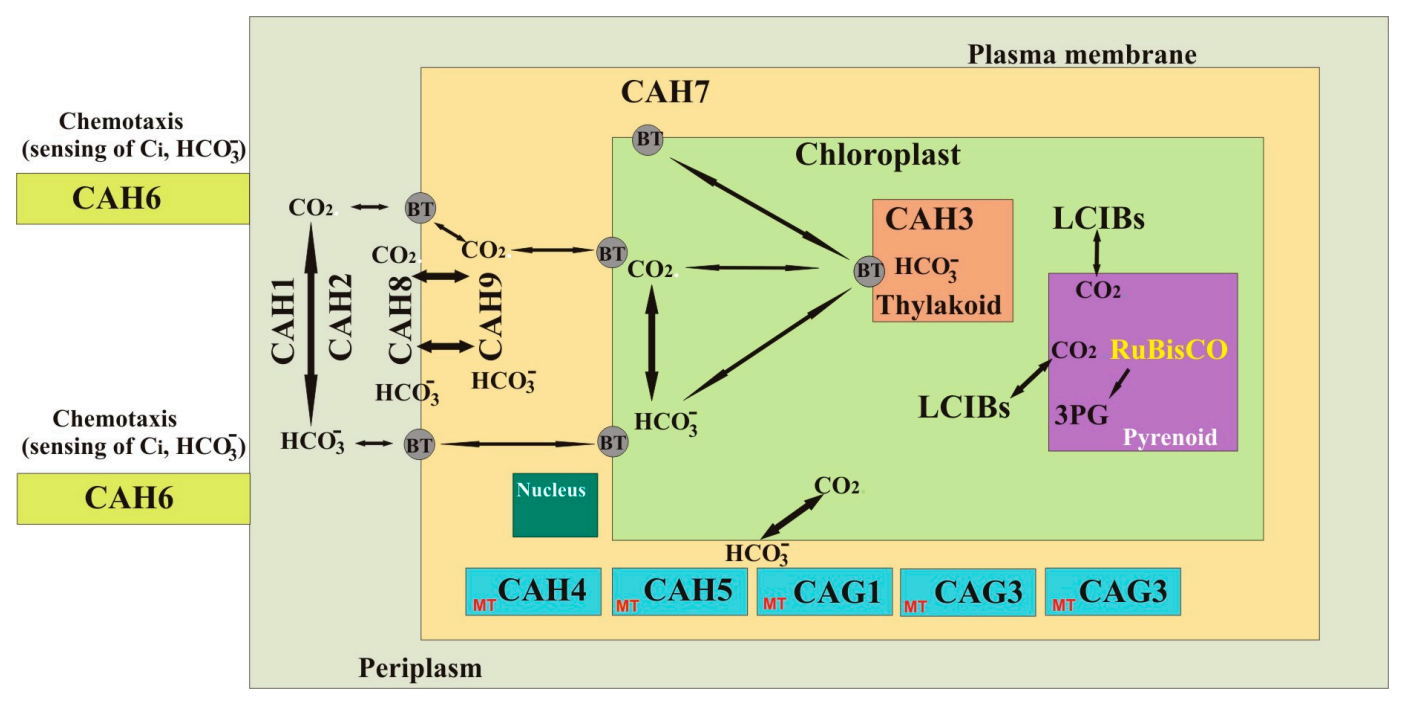

Figure 2. Schematic presentation of the $C$. reinhardtii model showing the roles of CAs in the cell and subcellular organelles. CAH1, CAH2, CAH3: $\alpha$-Carbonic anhydrases; CAH4, CAH5, CAH6, CAH7, CAH8, and CAH9: $\beta$-Carbonic anhydrases; LCIB1, LICB2, and LCIB3: Low $\mathrm{CO}_{2}$-inducible proteins ( $\beta$-CAs); CAG1, CAG2, and CAG3: $\gamma$-Carbonic anhydrases; BT: Bicarbonate transporters; RuBisCO: Ribulose-1,5-bisphosphate carboxylase oxygenase; 3PG: 3-phosphoglycerate. MT: mitochondria.

\section{Conclusions and Future Directions}

The CA enzymes belonging to different classes of CA gene families are found in vertebrates, invertebrates, plants, unicellular marine and fresh water algae, bacteria, and archaea. The CAs are localized in almost all of the tissues of higher animals and subcellular organelles of eukaryotic cells, and perform a variety of metabolic and physiological roles. In plants, several classes of CAs are found that are localized in subcellular organelles, are involved in CCM for photosynthesis, and perform other metabolic functions. Plant biologists have used marine and fresh water unicellular photosynthetic model organisms in order to study the precise metabolic roles of CA enzymes. The freshwater alga C. reinhardtii is one such model organism that has helped us to understand the metabolic and physiological roles of CAs mainly on CCM. However, the precise metabolic roles of most of the CA enzymes in this alga remain to be studied.

There has been a continuous interest in CA research in unicellular photosynthetic organisms, especially as the genomes of these algae have become available. The availability of bioinformatic and molecular tools has helped to study the precise metabolic roles of CAs in photosynthetic model organisms. In C. reinhardtii, researchers have attempted to study the localization and metabolic roles of three $\alpha$-CAs. Contradictory reports have emerged on the precise localizations of the CAs, and only limited information is available on the physiological roles of six $\beta$-CAs and the newly reported LCIB protein family that belongs to the $\beta$-CA group. No studies are available on $\gamma$-CAs except the presence of three forms of this enzyme and their predicated localization in the mitochondrial matrix. The challenge for future researchers will be to determine the precise localization and biochemical roles of all 12 CAs and the newly discovered three LCIB family proteins. 
It is important to identify the precise physiological roles for all of the CAs found in C. reinhardtii, which is an important model organism for studying fundamental processes such as photosynthesis. C. reinhardtii is the most commonly studied species of Chlamydomonas and has a relatively simple genome, which has been sequenced in many different strains, including the nonmotile strains. More importantly, various strains of $C$. reinhardtii have been developed for specific research purposes. In photosynthetic organisms, including $C$. reinhardtii, the role of CAs in CCM have been studied extensively. In addition to the fundamental roles of CAs in the reversible hydration of $\mathrm{CO}_{2}$, CAs have been shown to play important roles in defense mechanisms in plants and animals, protozoa, and bacteria. Therefore, it will be important to widen the perspective of CA studies in C. reinhardtii to cover not only $\mathrm{pH}$ regulation, but also other potential processes.

Acknowledgments: The work was supported by grants from the Sigrid Jusélius Foundation and the Academy of Finland to Seppo Parkkila and by a Finnish Cultural Foundation grant to Ashok Aspatwar.

Author Contributions: A.A. and S.H. are responsible for preparing the manuscript. A.A., S.H. and S.P. contributed to the writing of the article and have read and approved the final version.

Conflicts of Interest: The authors declare no conflict of interest.

\section{References}

1. Del Prete, S.; Vullo, D.; De Luca, V.; AlOthman, Z.; Osman, S.M.; Supuran, C.T.; Capasso, C. Biochemical characterization of recombinant beta-carbonic anhydrase (PgiCAb) identified in the genome of the oral pathogenic bacterium Porphyromonas gingivalis. J. Enzyme Inhib. Med. Chem. 2015, 30, 366-370. [CrossRef] [PubMed]

2. Supuran, C.T.; Capasso, C. The eta-class carbonic anhydrases as drug targets for antimalarial agents. Expert Opin. Ther. Targets 2015, 19, 551-563. [CrossRef] [PubMed]

3. Krishnamurthy, V.M.; Kaufman, G.K.; Urbach, A.R.; Gitlin, I.; Gudiksen, K.L.; Weibel, D.B.; Whitesides, G.M. Carbonic anhydrase as a model for biophysical and physical-organic studies of proteins and protein-ligand binding. Chem. Rev. 2008, 108, 946-1051. [CrossRef] [PubMed]

4. Kikutani, S.; Nakajima, K.; Nagasato, C.; Tsuji, Y.; Miyatake, A.; Matsuda, Y. Thylakoid luminal theta-carbonic anhydrase critical for growth and photosynthesis in the marine diatom Phaeodactylum tricornutum. Proc. Natl. Acad. Sci. USA 2016, 113, 9828-9833. [CrossRef] [PubMed]

5. Capasso, C.; Supuran, C.T. An overview of the alpha-, beta- and gamma-carbonic anhydrases from Bacteria: Can bacterial carbonic anhydrases shed new light on evolution of bacteria? J. Enzyme Inhib. Med. Chem. 2015, 30, 325-332. [CrossRef] [PubMed]

6. Floryszak-Wieczorek, J.; Arasimowicz-Jelonek, M. The multifunctional face of plant carbonic anhydrase. Plant Physiol. Biochem. 2017, 11, 362-368. [CrossRef] [PubMed]

7. Supuran, C.T.; Capasso, C. An overview of the bacterial carbonic anhydrases. Metabolites 2017, 7, 56. [CrossRef] [PubMed]

8. Supuran, C.T. Carbonic anhydrases: Novel therapeutic applications for inhibitors and activators. Nat. Rev. Drug. Discov. 2008, 7, 168-181. [CrossRef] [PubMed]

9. DiMario, R.J.; Clayton, H.; Mukherjee, A.; Ludwig, M.; Moroney, J.V. Plant carbonic anhydrases: Structures, locations, evolution, and physiological roles. Mol. Plant 2017, 10, 30-46. [CrossRef] [PubMed]

10. Jin, S.; Sun, J.; Wunder, T.; Tang, D.; Cousins, A.B.; Sze, S.K.; Mueller-Cajar, O.; Gao, Y.G. Structural insights into the LCIB protein family reveals a new group of beta-carbonic anhydrases. Proc. Natl. Acad. Sci. USA 2016, 113, 14716-14721. [CrossRef] [PubMed]

11. Lindskog, S. Structure and mechanism of carbonic anhydrase. Pharmacol. Ther. 1997, 74, 1-20. [CrossRef]

12. Moroney, J.V.; Ma, Y.; Frey, W.D.; Fusilier, K.A.; Pham, T.T.; Simms, T.A.; DiMario, R.J.; Yang, J.; Mukherjee, B. The carbonic anhydrase isoforms of Chlamydomonas reinhardtii: Intracellular location, expression, and physiological roles. Photosynth. Res. 2011, 109, 133-149. [CrossRef] [PubMed]

13. Hanson, D.T.; Franklin, L.A.; Samuelsson, G.; Badger, M.R. The Chlamydomonas reinhardtii cia3 mutant lacking a thylakoid lumen-localized carbonic anhydrase is limited by $\mathrm{CO}_{2}$ supply to rubisco and not photosystem II function in vivo. Plant Physiol. 2003, 132, 2267-2275. [CrossRef] [PubMed] 
14. Mackinder, L.C.M.; Chen, C.; Leib, R.D.; Patena, W.; Blum, S.R.; Rodman, M.; Ramundo, S.; Adams, C.M.; Jonikas, M.C. A spatial interactome reveals the protein organization of the algal $\mathrm{CO}_{2}$-concentrating mechanism. Cell 2017, 171, 133-147.e14. [CrossRef] [PubMed]

15. Hoang, C.V.; Chapman, K.D. Biochemical and molecular inhibition of plastidial carbonic anhydrase reduces the incorporation of acetate into lipids in cotton embryos and tobacco cell suspensions and leaves. Plant Physiol. 2002, 128, 1417-1427. [CrossRef] [PubMed]

16. Henry, R.P. Multiple roles of carbonic anhydrase in cellular transport and metabolism. Annu. Rev. Physiol. 1996, 58, 523-538. [CrossRef] [PubMed]

17. Geers, C.; Gros, G. Carbon dioxide transport and carbonic anhydrase in blood and muscle. Physiol. Rev. 2000, 80, 681-715. [CrossRef] [PubMed]

18. Riccardi, D.; Yang, S.; Cui, Q. Proton transfer function of carbonic anhydrase: Insights from QM/MM simulations. Biochim. Biophys. Acta 2010, 1804, 342-351. [CrossRef] [PubMed]

19. Roy, A.; Taraphder, S. Role of protein motions on proton transfer pathways in human carbonic anhydrase II. Biochim. Biophys. Acta 2010, 1804, 352-361. [CrossRef] [PubMed]

20. Missner, A.; Kugler, P.; Saparov, S.M.; Sommer, K.; Mathai, J.C.; Zeidel, M.L.; Pohl, P. Carbon dioxide transport through membranes. J. Biol. Chem. 2008, 283, 25340-25347. [CrossRef] [PubMed]

21. Parkkila, S.; Parkkila, A.K.; Rajaniemi, H.; Shah, G.N.; Grubb, J.H.; Waheed, A.; Sly, W.S. Expression of membrane-associated carbonic anhydrase XIV on neurons and axons in mouse and human brain. Proc. Natl. Acad. Sci. USA 2001, 98, 1918-1923. [CrossRef] [PubMed]

22. Supuran, C.T. Structure-based drug discovery of carbonic anhydrase inhibitors. J. Enzyme Inhib. Med. Chem. 2012, 27, 759-772. [CrossRef] [PubMed]

23. Supuran, C.T. Carbonic anhydrases: Catalytic and inhibition mechanisms, distribution and physiological roles. In Carbonic Anhydrase: Its Inhibitors and Activators; Supuran, C.T., Scozzafava, A., Conway, J., Eds.; CRC Press: Boca Raton, FL, USA, 2004; pp. 1-23.

24. Chegwidden, W.R.; Dodgson, S.J.; Spencer, I.M. The Roles of Carbonic Anhydrase in Metabolism, Cell Growth and Cancer in Animals; Chegwidden, W.R., Carter, N.D., Edwards, Y.H., Eds.; Birkhäuser Verlag: Boston, MA, USA, 2000; Volume 90, pp. 343-363.

25. Woolley, P. Models for metal ion function in carbonic anhydrase. Nature 1975, 258, 677-682. [CrossRef] [PubMed]

26. Esbaugh, A.J.; Tufts, B.L. The structure and function of carbonic anhydrase isozymes in the respiratory system of vertebrates. Respir. Physiol. Neurobiol. 2006, 154, 185-198. [CrossRef] [PubMed]

27. Dodgson, S.J.; Forster, R.E., 2nd. Carbonic anhydrase: Inhibition results in decreased urea production by hepatocytes. J. Appl. Physiol. 1986, 60, 646-652. [CrossRef] [PubMed]

28. Gay, C.V.; Schraer, H.; Anderson, R.E.; Cao, H. Current studies on the location and function of carbonic anhydrase in osteoclasts. Ann. N. Y. Acad. Sci. 1984, 429, 473-478. [CrossRef] [PubMed]

29. Henry, R.P. The function of invertebrate carbonic anhydrase in ion transport. Ann. N. Y. Acad. Sci. 1984, 429, 544-546. [CrossRef] [PubMed]

30. Park, H.; Song, B.; Morel, F.M. Diversity of the cadmium-containing carbonic anhydrase in marine diatoms and natural waters. Environ. Microbiol. 2007, 9, 403-413. [CrossRef] [PubMed]

31. DiMario, R.J.; Machingura, M.C.; Waldrop, G.L.; Moroney, J.V. The many types of carbonic anhydrases in photosynthetic organisms. Plant Sci. 2018, 268, 11-17. [CrossRef] [PubMed]

32. Hewett-Emmett, D. Evolution and Distribution of the Carbonic Anhydrase Gene Families; Chegwidden, W.R., Carter, N.D., Edwards, Y.H., Eds.; Birkhäuser Verlag: Boston, MA, USA, 2000; Volume 90, pp. 29-76.

33. Xu, Y.; Feng, L.; Jeffrey, P.D.; Shi, Y.; Morel, F.M. Structure and metal exchange in the cadmium carbonic anhydrase of marine diatoms. Nature 2008, 452, 56-61. [CrossRef] [PubMed]

34. Smith, K.S.; Jakubzick, C.; Whittam, T.S.; Ferry, J.G. Carbonic anhydrase is an ancient enzyme widespread in prokaryotes. Proc. Natl. Acad. Sci. USA 1999, 96, 15184-15189. [CrossRef] [PubMed]

35. Roberts, S.B.; Lane, T.W.; Morel, F.M.M. Carbonic anhydrase in the marine diatom Thalassiosira weissflogii (Bacillariophyceae). J. Phycol. 1997, 33, 845-850. [CrossRef]

36. Soto, A.R.; Zheng, H.; Shoemaker, D.; Rodriguez, J.; Read, B.A.; Wahlund, T.M. Identification and preliminary characterization of two cDNAs encoding unique carbonic anhydrases from the marine alga Emiliania huxleyi. Appl. Environ. Microbiol. 2006, 72, 5500-5511. [CrossRef] [PubMed] 
37. De Simone, G.; Di Fiore, A.; Capasso, C.; Supuran, C.T. The zinc coordination pattern in the eta-carbonic anhydrase from Plasmodium falciparum is different from all other carbonic anhydrase genetic families. Bioorg. Med. Chem. Lett. 2015, 25, 1385-1389. [CrossRef] [PubMed]

38. Mangani, S.; Hakansson, K. Crystallographic studies of the binding of protonated and unprotonated inhibitors to carbonic anhydrase using hydrogen sulphide and nitrate anions. Eur. J. Biochem. 1992, 210, 867-871. [CrossRef] [PubMed]

39. West, D.; Kim, C.U.; Tu, C.; Robbins, A.H.; Gruner, S.M.; Silverman, D.N.; McKenna, R. Structural and kinetic effects on changes in the $\mathrm{CO}_{2}$ binding pocket of human carbonic anhydrase II. Biochemistry 2012, 51, 9156-9163. [CrossRef] [PubMed]

40. Cronk, J.D.; Rowlett, R.S.; Zhang, K.Y.; Tu, C.; Endrizzi, J.A.; Lee, J.; Gareiss, P.C.; Preiss, J.R. Identification of a novel noncatalytic bicarbonate binding site in eubacterial beta-carbonic anhydrase. Biochemistry 2006, 45, 4351-4361. [CrossRef] [PubMed]

41. Iverson, T.M.; Alber, B.E.; Kisker, C.; Ferry, J.G.; Rees, D.C. A closer look at the active site of gamma-class carbonic anhydrases: High-resolution crystallographic studies of the carbonic anhydrase from Methanosarcina thermophila. Biochemistry 2000, 39, 9222-9231. [CrossRef] [PubMed]

42. Kisker, C.; Schindelin, H.; Alber, B.E.; Ferry, J.G.; Rees, D.C. A left-hand beta-helix revealed by the crystal structure of a carbonic anhydrase from the archaeon Methanosarcina thermophila. EMBO J. 1996, 15, 2323-2330. [PubMed]

43. Brinkman, R.; Margaria, R.; Meldrum, N.; Roughton, F. The $\mathrm{CO}_{2}$ catalyst present in blood. J. Physiol. 1932, 75, 3-4.

44. Meldrum, N.; Roughton, F. Some properties of carbonic anhydrase, the $\mathrm{CO}_{2}$ enzyme present in blood. J. Physiol. 1932, 75, 15.

45. Aspatwar, A.; Tolvanen, M.E.; Parkkila, S. Phylogeny and expression of carbonic anhydrase-related proteins. BMC Mol. Biol. 2010, 11, 25. [CrossRef] [PubMed]

46. Neish, A.C. Studies on chloroplasts: Their chemical composition and the distribution of certain metabolites between the chloroplasts and the remainder of the leaf. Biochem. J. 1939, 33, 300-308. [CrossRef] [PubMed]

47. Supuran, C.T. Bacterial carbonic anhydrases as drug targets: Toward novel antibiotics? Front. Pharmacol. 2011, 2, 34. [CrossRef] [PubMed]

48. Cox, E.H.; McLendon, G.L.; Morel, F.M.; Lane, T.W.; Prince, R.C.; Pickering, I.J.; George, G.N. The active site structure of Thalassiosira weissflogii carbonic anhydrase 1. Biochemistry 2000, 39, 12128-12130. [CrossRef] [PubMed]

49. Suarez Covarrubias, A.; Larsson, A.M.; Hogbom, M.; Lindberg, J.; Bergfors, T.; Björkelid, C.; Mowbray, S.L.; Unge, T.; Jones, T.A. Structure and function of carbonic anhydrases from Mycobacterium tuberculosis. J. Biol. Chem. 2005, 280, 18782-18789. [CrossRef] [PubMed]

50. Kimber, M.S.; Pai, E.F. The active site architecture of Pisum sativum beta-carbonic anhydrase is a mirror image of that of alpha-carbonic anhydrases. EMBO J. 2000, 19, 1407-1418. [CrossRef] [PubMed]

51. Smith, K.S.; Cosper, N.J.; Stalhandske, C.; Scott, R.A.; Ferry, J.G. Structural and kinetic characterization of an archaeal beta-class carbonic anhydrase. J. Bacteriol. 2000, 182, 6605-6613. [CrossRef] [PubMed]

52. Strop, P.; Smith, K.S.; Iverson, T.M.; Ferry, J.G.; Rees, D.C. Crystal structure of the "cab"-type beta class carbonic anhydrase from the archaeon Methanobacterium thermoautotrophicum. J. Biol. Chem. 2001, 276, 10299-10305. [CrossRef] [PubMed]

53. Bury-Mone, S.; Mendz, G.L.; Ball, G.E.; Thibonnier, M.; Stingl, K.; Ecobichon, C.; Avé, P.; Huerre, M.; Labigne, A.; Thiberge, J.M.; et al. Roles of alpha and beta carbonic anhydrases of Helicobacter pylori in the urease-dependent response to acidity and in colonization of the murine gastric mucosa. Infect. Immun. 2008, 76, 497-509. [CrossRef] [PubMed]

54. Rose, S.J.; Bermudez, L.E. Identification of Bicarbonate as a Trigger and Genes Involved with Extracellular DNA Export in Mycobacterial Biofilms. mBio 2016, 7, 6. [CrossRef] [PubMed]

55. Johnson, B.K.; Colvin, C.J.; Needle, D.B.; Mba Medie, F.; Champion, P.A.; Abramovitch, R.B. The Carbonic Anhydrase Inhibitor Ethoxzolamide Inhibits the Mycobacterium tuberculosis PhoPR Regulon and Esx-1 Secretion and Attenuates Virulence. Antimicrob. Agents Chemother. 2015, 59, 4436-4445. [CrossRef] [PubMed]

56. Parisi, G.; Perales, M.; Fornasari, M.S.; Colaneri, A.; Gonzalez-Schain, N.; Gomez-Casati, D.; Zimmermann, S.; Brennicke, A.; Araya, A.; Ferry, J.G.; et al. Gamma carbonic anhydrases in plant mitochondria. Plant Mol. Biol. 2004, 55, 193-207. [CrossRef] [PubMed] 
57. Alber, B.E.; Ferry, J.G. A carbonic anhydrase from the archaeon Methanosarcina thermophila. Proc. Natl. Acad. Sci. USA 1994, 91, 6909-6913. [CrossRef] [PubMed]

58. Macauley, S.R.; Zimmerman, S.A.; Apolinario, E.E.; Evilia, C.; Hou, Y.M.; Ferry, J.G.; Sowers, K.R. The archetype gamma-class carbonic anhydrase, Cam, contains iron when synthesized in vivo. Biochemistry 2009, 48, 817-819. [CrossRef] [PubMed]

59. Alber, B.E.; Colangelo, C.M.; Dong, J.; Stalhandske, C.M.; Baird, T.T.; Tu, C.; Fierke, C.A.; Silverman, D.N.; Scott, R.A.; Ferry, J.G. Kinetic and spectroscopic characterization of the gamma-carbonic anhydrase from the methanoarchaeon Methanosarcina thermophila. Biochemistry 1999, 38, 13119-13128. [CrossRef] [PubMed]

60. Zimmerman, S.A.; Ferry, J.G. Proposal for a hydrogen bond network in the active site of the prototypic gamma-class carbonic anhydrase. Biochemistry 2006, 45, 5149-5157. [CrossRef] [PubMed]

61. McGinn, P.J.; Morel, F.M. Expression and regulation of carbonic anhydrases in the marine diatom Thalassiosira pseudonana and in natural phytoplankton assemblages from Great Bay, New Jersey. Physiol. Plant. 2008, 133, 78-91. [CrossRef] [PubMed]

62. Alterio, V.; Langella, E.; Viparelli, F.; Vullo, D.; Ascione, G.; Dathan, N.A.; Morel, F.M.; Supuran, C.T.; De Simone, G.; Monti, S.M. Structural and inhibition insights into carbonic anhydrase CDCA1 from the marine diatom Thalassiosira weissflogii. Biochimie 2012, 94, 1232-1241. [CrossRef] [PubMed]

63. Pena, K.L.; Castel, S.E.; de Araujo, C.; Espie, G.S.; Kimber, M.S. Structural basis of the oxidative activation of the carboxysomal gamma-carbonic anhydrase, CcmM. Proc. Natl. Acad. Sci. USA 2010, 107, 2455-2460. [CrossRef] [PubMed]

64. Price, G.D.; Howitt, SM.; Harrison, K.; Badger, M.R. Analysis of a genomic DNA region from the cyanobacterium Synechococcus sp. strain PCC7942 involved in carboxysome assembly and function. J. Bacteriol. 1993, 175, 2871-2879. [CrossRef] [PubMed]

65. Fukuzawa, H.; Fujiwara, S.; Yamamoto, Y.; Dionisio-Sese, M.L.; Miyachi, S. cDNA cloning, sequence, and expression of carbonic anhydrase in Chlamydomonas reinhardtii: Regulation by environmental $\mathrm{CO}_{2}$ concentration. Proc. Natl. Acad. Sci. USA 1990, 87, 4383-4387. [CrossRef] [PubMed]

66. Fujiwara, S.; Fukuzawa, H.; Tachiki, A.; Miyachi, S. Structure and differential expression of two genes encoding carbonic anhydrase in Chlamydomonas reinhardtii. Proc. Natl. Acad. Sci. USA 1990, 87, 9779-9783. [CrossRef] [PubMed]

67. Burnell, J.N.; Gibbs, M.J.; Mason, J.G. Spinach chloroplastic carbonic anhydrase: Nucleotide sequence analysis of cDNA. Plant Physiol. 1990, 92, 37-40. [CrossRef] [PubMed]

68. Fawcett, T.W.; Browse, J.A.; Volokita, M.; Bartlett, S.G. Spinach carbonic anhydrase primary structure deduced from the sequence of a cDNA clone. J. Biol. Chem. 1990, 265, 5414-5417. [PubMed]

69. Roeske, C.A.; Ogren, W.L. Nucleotide sequence of pea cDNA encoding chloroplast carbonic anhydrase. Nucleic Acids Res. 1990, 18, 3413. [CrossRef] [PubMed]

70. Mitra, M.; Mason, C.; Lato, S.M.; Ynalvez, R.A.; Xiao, Y.; Moroney, J.V. The carbonic anhydrase gene families of Chlamydomonas reinhardtii. Can. J. Bot. 2005, 83, 780-795. [CrossRef]

71. Cardol, P.; Gonzalez-Halphen, D.; Reyes-Prieto, A.; Baurain, D.; Matagne, R.F.; Remacle, C. The mitochondrial oxidative phosphorylation proteome of Chlamydomonas reinhardtii deduced from the Genome Sequencing Project. Plant Physiol. 2005, 137, 447-459. [CrossRef] [PubMed]

72. Price, G.D.; Badger, M.R.; Woodger, F.J.; Long, B.M. Advances in understanding the cyanobacterial $\mathrm{CO}_{2}$-concentrating-mechanism, $\mathrm{CCM}$, functional components, $\mathrm{Ci}$ transporters, diversity, genetic regulation and prospects for engineering into plants. J. Exp. Bot. 2008, 59, 1441-1461. [CrossRef] [PubMed]

73. Toguri, T.; Muto, S.; Miyachi, S. Biosynthesis and intracellular processing of carbonic anhydrase in Chlamydomonas reinhardtii. Eur. J. Biochem. 1986, 158, 443-450. [CrossRef] [PubMed]

74. Kucho, K.; Yoshioka, S.; Taniguchi, F.; Ohyama, K.; Fukuzawa, H. Cis-acting elements and DNA-binding proteins involved in $\mathrm{CO}_{2}$-responsive transcriptional activation of Cah1 encoding a periplasmic carbonic anhydrase in Chlamydomonas reinhardtii. Plant Physiol. 2003, 133, 783-793. [CrossRef] [PubMed]

75. Kucho, K.; Ohyama, K.; Fukuzawa, H. $\mathrm{CO}_{2}$-responsive transcriptional regulation of CAH1 encoding carbonic anhydrase is mediated by enhancer and silencer regions in Chlamydomonas reinhardtii. Plant Physiol. 1999, 121, 1329-1337. [CrossRef] [PubMed]

76. Juvale, P.S.; Wagner, R.L.; Spalding, M.H. Opportunistic proteolytic processing of carbonic anhydrase 1 from Chlamydomonas in Arabidopsis reveals a novel route for protein maturation. J. Exp. Bot. 2016, 67, 2339-2351. [CrossRef] [PubMed] 
77. Ishida, S.; Muto, S.; Miyachi, S. Structural analysis of periplasmic carbonic anhydrase 1 of Chlamydomonas reinhardtii. Eur. J. Biochem. 1993, 214, 9-16. [CrossRef] [PubMed]

78. Kamo, T.; Shimogawara, K.; Fukuzawa, H.; Muto, S.; Miyachi, S. Subunit constitution of carbonic anhydrase from Chlamydomonas reinhardtii. Eur. J. Biochem. 1990, 192, 557-562. [CrossRef] [PubMed]

79. Yoshioka, S.; Taniguchi, F.; Miura, K.; Inoue, T.; Yamano, T.; Fukuzawa, H. The novel Myb transcription factor LCR1 regulates the $\mathrm{CO}_{2}$-responsive gene Cah1, encoding a periplasmic carbonic anhydrase in Chlamydomonas reinhardtii. Plant Cell 2004, 16, 1466-1477. [CrossRef] [PubMed]

80. Tachiki, A.; Fukuzawa, H.; Miyachi, S. Characterization of carbonic anhydrase isozyme CA2, which is the CAH2 gene product, in Chlamydomonas reinhardtii. Biosci. Biotechnol. Biochem. 1992, 56, 794-798. [CrossRef] [PubMed]

81. Rawat, M.; Moroney, J.V. Partial, characterization of a new isoenzyme of carbonic anhydrase isolated from Chlamydomonas reinhardtii. J. Biol. Chem. 1991, 266, 9719-9723. [PubMed]

82. Karlsson, J.; Clarke, A.K.; Chen, Z.Y.; Hugghins, S.Y.; Park, Y.I.; Husic, H.D.; Moroney, J.V.; Samuelsson, G. A novel alpha-type carbonic anhydrase associated with the thylakoid membrane in Chlamydomonas reinhardtii is required for growth at ambient $\mathrm{CO}_{2}$. EMBO J. 1998, 17, 1208-1216. [PubMed]

83. Funke, R.P.; Kovar, J.L.; Weeks, D.P. Intracellular carbonic anhydrase is essential to photosynthesis in Chlamydomonas reinhardtii at atmospheric levels of $\mathrm{CO}_{2}$ : Demonstration via genomic complementation of the high- $\mathrm{CO}_{2}$-requiring mutant ca-1. Plant Physiol. 1997, 114, 237-244. [CrossRef] [PubMed]

84. Karlsson, J.; Hiltonen, T.; Husic, H.D.; Ramazanov, Z.; Samuelsson, G. Intracellular carbonic anhydrase of Chlamydomonas reinhardtii. Plant Physiol. 1995, 109, 533-539. [CrossRef] [PubMed]

85. Blanco-Rivero, A.; Shutova, T.; Roman, M.J.; Villarejo, A.; Martinez, F. Phosphorylation controls the localization and activation of the lumenal carbonic anhydrase in Chlamydomonas reinhardtii. PLoS ONE 2012, 7, e49063. [CrossRef] [PubMed]

86. Park, Y.I.; Karlsson, J.; Rojdestvenski, I.; Pronina, N.; Klimov, V.; Oquist, G.; Samuelsson, G. Role of a novel photosystem II-associated carbonic anhydrase in photosynthetic carbon assimilation in Chlamydomonas reinhardtii. FEBS Lett. 1999, 444, 102-105. [CrossRef]

87. Benlloch, R.; Shevela, D.; Hainzl, T.; Grundstrom, C.; Shutova, T.; Messinger, J.; Samuelsson, G.; Sauer-Eriksson, A.E. Crystal structure and functional characterization of photosystem II-associated carbonic anhydrase CAH3 in Chlamydomonas reinhardtii. Plant Physiol. 2015, 167, 950-962. [CrossRef] [PubMed]

88. Sinetova, M.A.; Kupriyanova, E.V.; Markelova, A.G.; Allakhverdiev, S.I.; Pronina, N.A. Identification and functional role of the carbonic anhydrase Cah3 in thylakoid membranes of pyrenoid of Chlamydomonas reinhardtii. Biochim. Biophys. Acta 2012, 1817, 1248-1255. [CrossRef] [PubMed]

89. Giordano, M.; Norici, A.; Forssen, M.; Eriksson, M.; Raven, J.A. An anaplerotic role for mitochondrial carbonic anhydrase in Chlamydomonas reinhardtii. Plant Physiol. 2003, 132, 2126-2134. [CrossRef] [PubMed]

90. Villand, P.; Eriksson, M.; Samuelsson, G. Carbon dioxide and light regulation of promoters controlling the expression of mitochondrial carbonic anhydrase in Chlamydomonas reinhardtii. Biochem. J. 1997, 327, 51-57. [CrossRef] [PubMed]

91. Eriksson, M.; Karlsson, J.; Ramazanov, Z.; Gardestrom, P.; Samuelsson, G. Discovery of an algal mitochondrial carbonic anhydrase: Molecular cloning and characterization of a low- $\mathrm{CO}_{2}$-induced polypeptide in Chlamydomonas reinhardtii. Proc. Natl. Acad. Sci. USA 1996, 93, 12031-12034. [CrossRef] [PubMed]

92. Ynalvez, R.A.; Xiao, Y.; Ward, A.S.; Cunnusamy, K.; Moroney, J.V. Identification and characterization of two closely related beta-carbonic anhydrases from Chlamydomonas reinhardtii. Physiol. Plant. 2008, 133, 15-26. [CrossRef] [PubMed]

93. Cardol, P.; Vanrobaeys, F.; Devreese, B.; Van Beeumen, J.; Matagne, R.F.; Remacle, C. Higher plant-like subunit composition of mitochondrial complex I from Chlamydomonas reinhardtii: 31 conserved components among eukaryotes. Biochim. Biophys. Acta 2004, 1658, 212-224. [CrossRef] [PubMed]

94. Coleman, J.R.; Berry, J.A.; Togasaki, R.K.; Grossman, A.R. Identification of Extracellular Carbonic Anhydrase of Chlamydomonas reinhardtii. Plant Physiol. 1984, 76, 472-477. [CrossRef] [PubMed]

95. Villarejo, A.; Shutova, T.; Moskvin, O.; Forssen, M.; Klimov, V.V.; Samuelsson, G. A photosystem II-associated carbonic anhydrase regulates the efficiency of photosynthetic oxygen evolution. EMBO J. 2002, 21, 1930-1938. [CrossRef] [PubMed] 
96. Shutova, T.; Kenneweg, H.; Buchta, J.; Nikitina, J.; Terentyev, V.; Chernyshov, S.; Andersson, B.; Allakhverdiev, S.I.; Klimov, V.V.; Dau, H.; et al. The photosystem II-associated Cah3 in Chlamydomonas enhances the $\mathrm{O}_{2}$ evolution rate by proton removal. EMBO J. 2008, 27, 782-791. [CrossRef] [PubMed]

97. Mitra, M.; Lato, S.M.; Ynalvez, R.A.; Xiao, Y.; Moroney, J.V. Identification of a new chloroplast carbonic anhydrase in Chlamydomonas reinhardtii. Plant Physiol. 2004, 135, 173-182. [CrossRef] [PubMed]

98. Wang, Y.; Stessman, D.J.; Spalding, M.H. The $\mathrm{CO}_{2}$ concentrating mechanism and photosynthetic carbon assimilation in limiting $\mathrm{CO}_{2}$ : How Chlamydomonas works against the gradient. Plant J. 2015, 82, 429-448. [CrossRef] [PubMed]

99. Price, G.D.; Badger, M.R. Expression of Human Carbonic Anhydrase in the Cyanobacterium Synechococcus PCC7942 Creates a High $\mathrm{CO}_{2}$-Requiring Phenotype: Evidence for a Central Role for Carboxysomes in the $\mathrm{CO}_{2}$ Concentrating Mechanism. Plant Physiol. 1989, 91, 505-513. [CrossRef] [PubMed]

100. Choi, H.I.; Kim, J.Y. Quantitative analysis of the chemotaxis of a green alga, Chlamydomonas reinhardtii, to bicarbonate using diffusion-based microfluidic device. Biomicrofluidics 2016, 10, 014121. [CrossRef] [PubMed]

101. Hu, H.; Boisson-Dernier, A.; Israelsson-Nordstrom, M.; Bohmer, M.; Xue, S.; Ries, A.; Godoski, J.; Kuhn, J.M.; Schroeder, J.I. Carbonic anhydrases are upstream regulators of $\mathrm{CO}_{2}$-controlled stomatal movements in guard cells. Nat. Cell Biol. 2010, 12, 87-93. [CrossRef] [PubMed]

102. Fromm, S.; Braun, H.P.; Peterhansel, C. Mitochondrial gamma carbonic anhydrases are required for complex I assembly and plant reproductive development. New Phytol. 2016, 211, 194-207. [CrossRef] [PubMed]

(C) 2018 by the authors. Licensee MDPI, Basel, Switzerland. This article is an open access article distributed under the terms and conditions of the Creative Commons Attribution (CC BY) license (http:/ / creativecommons.org/licenses/by/4.0/). 